\title{
BIODIESEL PRODUCTION FROM COCONUT OIL USING HETEROGENEOUS CATALYST DERIVED FROM ITS POD
}

\author{
Adebayo, A.O ${ }^{1 *}$., Oniya, O.O $^{1}$., Ogunsola, D.A ${ }^{2}$, Ogunkunle, $\mathrm{O}^{3}$., Bello, A.I ${ }^{1}$ and Kuku, A.T ${ }^{1}$ \\ ${ }^{1}$ Department of Agricultural Engineering, Faculty of Engineering and Technology, Ladoke Akintola \\ University of Technology, Ogbomoso, Nigeria \\ ${ }^{2}$ Department of Mechanical Engineering, Faculty of Engineering and Technology, Ladoke Akintola \\ University of Technology, Ogbomoso, Nigeria \\ ${ }^{3}$ Department of Mechanical Engineering Science, Faculty of Engineering and the Built Environment, \\ University of Johannesburg, South Africa. \\ *Corresponding Author
}

\begin{abstract}
Production of biofuel from renewable biomass has become a popular way of converting waste to wealth. In this research, coconut (Cocos nucifera) was investigated as a renewable energy source. Oil was extracted from the nut for biodiesel production while the pod was used for synthesis of heterogeneous catalyst required for its transesterification. The moisture content of the coconut pod was determined before being calcinated at different temperatures. The transesterification process was prepared using ethanol as alcohol. The reaction time ranged between 30 minutes to 1 hour, ethanol-to-oil ratio of 9:1, while the catalyst concentration that was used was 10 $w t \%$. Biodiesel yield of $6 \mathrm{ml}$ was recorded experimentally as the highest yield when temperature, reaction time, and alcohol-to-oil ratio were at constant temperature, 1 hour, and 9:1, respectively. Coconut pod was found to have a high percentage of $\mathrm{K}_{2} \mathrm{O}$ catalyst in biodiesel production. The usefulness of its oil and pod makes it an industrial feedstock for biofuel production.
\end{abstract}

Keywords: Biomass; coconut; transesterification; biodiesel; heterogeneous catalyst.

Cite this Article: Adebayo, A.O.; Oniya, O.O.; Ogunsola, D. A.; Ogunkunle, O; Bello, A.I. and Kuku, A.T. Biodiesel Production from Coconut Oil using Heterogeneous Catalyst Derived from its Pod, International Journal of Mechanical Engineering and Technology (IJMET), 12(8), 2021, pp. 1-10.

https://iaeme.com/Home/issue/IJMET?Volume $=12 \&$ Issue $=8$

\section{INTRODUCTION}

Biodiesel has recently attracted much attention all over the world as an alternative oxygenated fuel because of its renewability, similarity to fossil diesel in terms of fuel properties, superior lubricating properties, low zero sulphur content, and clean emission profile. Relative to these advantages, biodiesel has long term potential to replace fossil diesel in engine applications 
(Ramadhas et al., 2004). Biodiesel is traditionally produced from vegetable oils through transesterification process, which is also known as alcoholysis. This chemical reaction involves mixing of vegetable oil or animal fat with an alcohol, such as methanol or ethanol, in the presence of a catalyst. This reaction is mostly carried out in stirred reactors to yield mono alkyl esters and glycerine, a by-product which is eventually removed (Hossain et al., 2010). Biodiesel is commercially made by chemically reacting vegetable oil or animal fat or a combination of oils and fats with alcohol, usually nearly pure methanol, denatured ethanol or ethanol. The mixture is then combined with a catalyst, an alkaline chemical such as potassium hydroxide or sodium hydroxide, which is also known as lye. The oil is chemically acidic. The combination of the alcohol and catalyst, commonly termed as methoxide, is chemically a base. This chemical reaction breaks the fat molecules into an ester, which is the biodiesel fuel, and glycerol, a byproduct which is eventually removed (Narayana Reddy \& Ramesh, 2006; Vonortas \& Papayannakos, 2014).

According to statistics on world leading biodiesel producers, biodiesel is produced from transesterification of refined vegetable oils, including canola, palm, sunflower and soybean (Doll et al., 2008; Qiu et al., 2011) with methanol. Production of biodiesel from other oils such as coconut, cottonseed (Keskin et al., 2008; Meneghetti et al., 2006; Rashid et al., 2009), olive (Akgün \& İşcan, 2007; Baydar \& Turgut, 1999), rapeseed (Qiu et al., 2011; Reza Miri et al., 2017) etc. have also been reported. Literature reports have shown that the yields of oil expressed or extracted from different seed plants vary. Production of biodiesel production from populous seed oils, such as palm oil, groundnut oil, soy oil, Pongamia pinnata and Jatropha curcas, have been investigated in several literatures under different applied reaction variables like molar ratio of alcohol to oil, temperature, catalyst amount/concentration, time, and stirring rate (BankovićIlić et al., 2012; Quintella et al., 2012; Singh \& Singh, 2010). The use biodiesel in combustion ignition engines currently is promising based on the associated performance and emissions characteristics (Ogunkunle \& Ahmed, 2019). Tan and Man (Tan \& Che Man, 2002) reported a reduction in net $\mathrm{CO}_{2}$ emissions are estimated at 77-104g from biodiesel combustion in place of fossil diesel.

Coconut shell is an agricultural waste and available in large quantities throughout tropical countries worldwide (Archana et al., 2020; Obeng et al., 2020). In many countries, coconut shell is subjected to open burning which contributes significantly to $\mathrm{CO}_{2}$ and methane emission. Coconut shell is widely used for making charcoal. The traditional pit-method of production has a charcoal yield of 25-30\% of the dry weight of shells used (Kabir Ahmad et al., 2021). The charcoal produced by these methods affects the quality and is often contaminated with extraneous matter and soil. Activated carbon is manufactured from coconut shell which is regarded to be extremely effective for the removal of impurities in waste water treatment processes (Zhao et al., 2019). The coconut shell has a higher calorific value of $20.8 \mathrm{MJKg}$ and can be used to produce steam, energy-rich gases, bio-oil, and briquettes, which are good sources of fuel particularly in rural areas where domestic fuel is a challenge. Coconut is produced in 92 countries worldwide on more than ten million hectares (Jackson et al., 2004). Indonesia, Philippines, and India account for almost $75 \%$ of world coconut production with Indonesia being the world's largest coconut producer (Pham, 2016). A coconut plantation is a source of a wide variety of products such as coir yarn for the weaving of coir mats, fiber mats, rugs, and carpets, organic fertilizer, animal feed, fuel additive for cleaner emissions and healthy drink etc (Agyemang-Yeboah, 2011). The major advantage of using coconut is that it is a perennial crop which is available all year round in Nigeria so there is constant supply whole year. Northern regions with short growing seasons have limited total production potential. 


\section{METHODOLOGY}

The dried coconut biomass was then grinded to minute pieces before being calcinated at the same temperature and time. The transesterification process was prepared using ethanol as alcohol. $\mathrm{K}_{2} \mathrm{O}$ was the heterogeneous catalyst used. The experiment was prepared at temperature below the boiling point of ethanol. The reaction time ranged between 30minutes to 1 hour. Ethanol-to-oil ratio ranged 'between' 9:1. The catalyst concentration that was used in this work was $10 \mathrm{wt} \%$. The transesterification reaction was performed using reflux reaction. Biodiesel yield of $6 \mathrm{ml}$ was recorded experimentally as the highest yield when temperature, reaction time, and alcohol-to-oil ratio were at constant temperature of $75^{\circ} \mathrm{C}, 1$ hour, and 9:1, respectively. Coconut pod has a high percentage to be heterogeneous catalyst in biodiesel production.

\subsection{Experimental Materials}

The coconuts used in this study were purchased around Under G area of Ogbomoso, Oyo state, Nigeria. Other laboratory materials used include a round bottom flask, condenser, water pump, hose, water, hot plate, measuring cylinder, beaker, oven, magnetic stirrer, separating funnels, retort stand, lighter, spatula, and analytical balance.

\subsection{Preparation and Characterization of Coconut Pod Ash}

Coconut pod was washed with deionized water and dried under sunlight. Then the catalysts were prepared via calcination of coconut pod at different temperatures, varying from $100{ }^{\circ} \mathrm{C}$ to $900{ }^{\circ} \mathrm{C}$. Coconut pod (Plate 1a) was dried in a cleaned muffle furnace under the selected temperature for $4 \mathrm{hrs}$, and then grinded into fine grains (Plate 1b). The coconut pod ash derived as catalyst for biodiesel production are designated as CPAT; where CPA represents the short form of coconut pod ash and ' $\mathrm{T}$ ' indicates the catalyst treatment temperature in ${ }^{\circ} \mathrm{C}$. For example, the catalyst treated at $100{ }^{\circ} \mathrm{C}$ is designated as CPA100. The catalytic activity of the CPA derived catalyst was investigated in the transesterification of coconut oil.

Temperature of $100{ }^{\circ} \mathrm{C}$ was used for the purpose of comparison. It is required to show us how the characteristics of the material before being heated to various temperatures. Every other samples prepared at higher temperatures are expected to be used for the production of biodiesel, but the major focus was more on the use of the particular sample with highest score of $\mathrm{K}_{2} \mathrm{O}$. Other temperatures, at which CPA was prepared are $400{ }^{\circ} \mathrm{C}, 600^{\circ} \mathrm{C}, 800{ }^{\circ} \mathrm{C}$, and $900{ }^{\circ} \mathrm{C}$. All of these temperatures were tested to find out if their CPA have higher score than that of $100{ }^{\circ} \mathrm{C}$. The prepared CPA were characterized using X-Ray Diffraction (XRD) Analysis to determine the crystallographic structure of the samples.

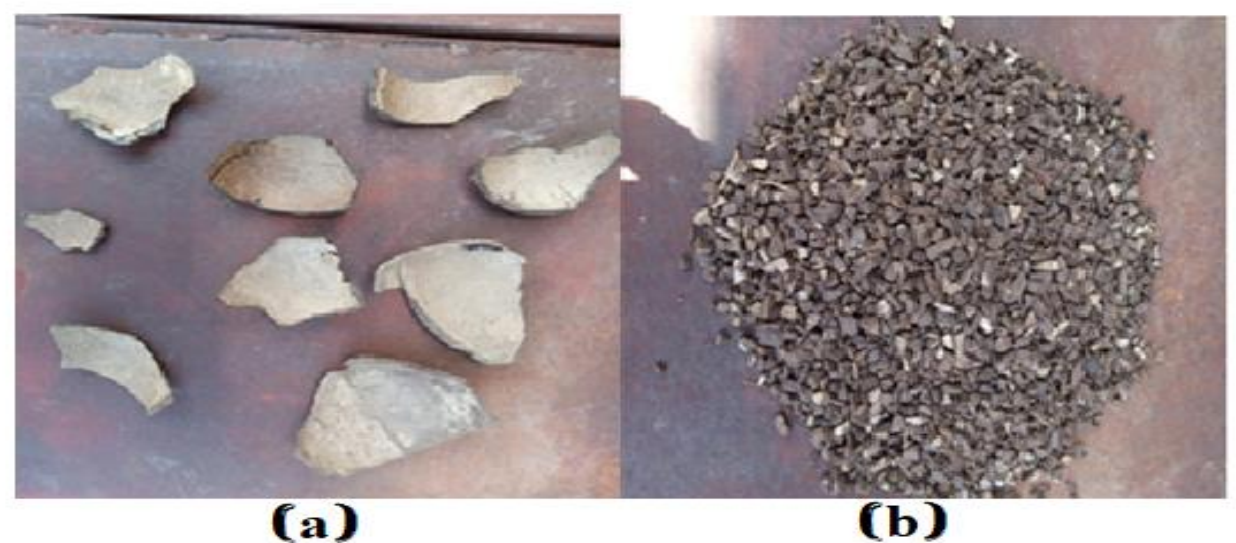

Plate 1(a): Coconut pod; (b) Fine particles of coconut pod 


\subsection{Transesterification of Extracted Coconut Oil}

A condenser was mounted on a $500 \mathrm{ml}$ round bottom flask with an inlet and outlet hose connected to a pumping motor in a reflux reaction set up (Plate 2). 180ml of ethanol was measured and added to $200 \mathrm{~g}$ of oil in a round bottom flask equipped with a magnetic stirrer. Then, catalyst amount of $10 \%$ of oil weight was added to it and placed on a hot plate. The reaction was allowed to reach its boiling point and then left for 1 hour. The reaction products were allowed to cool a little before being separated using separating funnels. After 24 hours of separation, different phases of biodiesel and glycerol were obtained. The biodiesel obtained was washed with water and dried in an oven to remove any existing moisture.

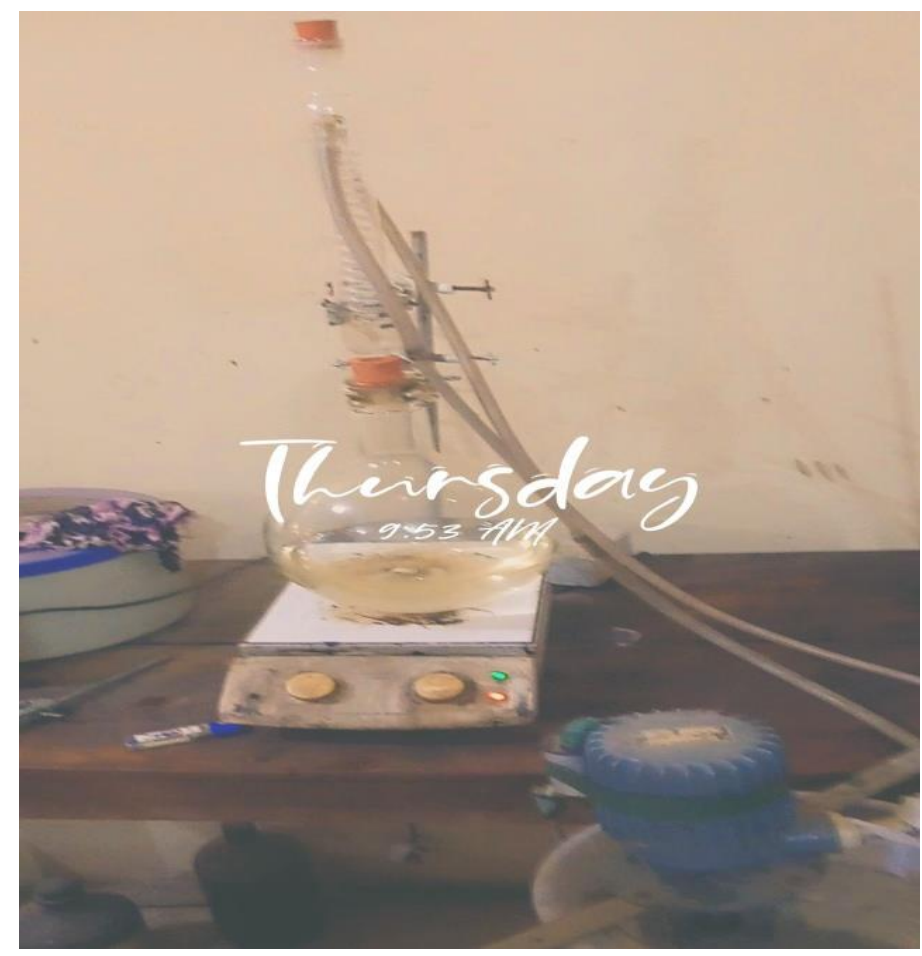

Plate 2 Experimental set up

\section{RESULTS AND DISCUSSION}

\subsection{Characterization of CPA at different Temperatures}

The identified patterns for synthesized catalyst at the selected temperature levels are presented in Tables $1-5$. The various scores of $\mathrm{K}_{2} \mathrm{O}$ in the prepared CPA samples at temperatures of 100 ${ }^{\circ} \mathrm{C}, 400{ }^{\circ} \mathrm{C}, 600{ }^{\circ} \mathrm{C}, 800{ }^{\circ} \mathrm{C}$, and $900{ }^{\circ} \mathrm{C}$ are shown in these tables.

Table 1 Identified pattern list for $100^{\circ} \mathrm{C}$

\begin{tabular}{|c|c|c|c|c|c|c|c|}
\hline Visible & $\begin{array}{c}\text { Ref. } \\
\text { Code }\end{array}$ & Score & $\begin{array}{c}\text { Compound } \\
\text { Name }\end{array}$ & $\begin{array}{c}\text { Displacement } \\
{\left[{ }^{\circ} \text { 2Th.] }\right.}\end{array}$ & $\begin{array}{c}\text { Scale } \\
\text { Factor }\end{array}$ & $\begin{array}{c}\text { Chemical } \\
\text { Formula }\end{array}$ \\
\hline$*$ & $39-0697$ & & 4 & $\begin{array}{c}\text { Potassium } \\
\text { Oxide }\end{array}$ & 0.000 & 1.261 & $\mathrm{~K}_{2} \mathrm{O}$ \\
\hline$*$ & $71-1178$ & & 7 & Cobalt Oxide & 0.000 & 0.407 & $\mathrm{CoO}$ \\
\hline$*$ & $12-0264$ & & 3 & $\begin{array}{c}\text { Potassium } \\
\text { Manganese } \\
\text { Oxide }\end{array}$ & 0.000 & 1.117 & $\mathrm{~K}_{2} \mathrm{MnO}_{4}$ \\
\hline$*$ & $89-1554$ & & 2 & $\begin{array}{c}\text { Molybdenum } \\
\text { Oxide }\end{array}$ & 0.000 & 0.314 & $\mathrm{MoO}_{2}$ \\
\hline
\end{tabular}


Adebayo, A.O.; Oniya, O.O.; Ogunsola, D. A.; Ogunkunle, O; Bello, A.I. and Kuku, A.T

Table 2 Identified pattern list for $400^{\circ} \mathrm{C}$

\begin{tabular}{|c|c|c|l|c|c|c|}
\hline Visible & Ref. Code & Score & $\begin{array}{l}\text { Compound } \\
\text { Name }\end{array}$ & $\begin{array}{c}\text { Displacement } \\
{\left[{ }^{\circ} \text { 2Th.] }\right.}\end{array}$ & $\begin{array}{c}\text { Scale } \\
\text { Factor }\end{array}$ & $\begin{array}{c}\text { Chemical } \\
\text { Formula }\end{array}$ \\
\hline$*$ & $23-0493$ & 8 & $\begin{array}{l}\text { Potassium } \\
\text { Oxide }\end{array}$ & 0.000 & 0.040 & $\mathrm{~K}_{2} \mathrm{O}$ \\
\hline$*$ & $75-1526$ & 13 & Zincite & 0.000 & 0.093 & $\mathrm{ZnO}$ \\
\hline$*$ & $74-2392$ & 24 & Cobalt Oxide & 0.000 & 0.070 & $\mathrm{CoO}$ \\
\hline$*$ & $45-0142$ & 5 & $\begin{array}{l}\text { Nickel } \\
\text { Molybdenum } \\
\text { Oxide }\end{array}$ & 0.000 & 0.232 & $\mathrm{NiMoO}$ \\
\hline$*$ & $21-0155$ & 4 & Calcium Oxide & 0.000 & 0.188 & $\mathrm{CaO}_{4}$ \\
\hline$*$ & $27-0434$ & 4 & $\begin{array}{l}\text { Potassium } \\
\text { Palladium } \\
\text { Oxide }\end{array}$ & 0.000 & 0.075 & $\mathrm{~K}_{2} \mathrm{PdO}_{2}$ \\
& & & & & \\
\hline
\end{tabular}

Table 3 Identified pattern list for $600^{\circ} \mathrm{C}$

\begin{tabular}{|c|c|c|l|c|c|c|}
\hline Visible & Ref. Code & Score & $\begin{array}{l}\text { Compound } \\
\text { Name }\end{array}$ & $\begin{array}{c}\text { Displacement } \\
{\left[{ }^{\circ} \text { 2Th. }\right.}\end{array}$ & $\begin{array}{c}\text { Scale } \\
\text { Factor }\end{array}$ & $\begin{array}{c}\text { Chemical } \\
\text { Formula }\end{array}$ \\
\hline$*$ & $23-0493$ & 16 & $\begin{array}{l}\text { Potassium } \\
\text { Oxide }\end{array}$ & 0.000 & 0.086 & $\mathrm{~K}_{2} \mathrm{O}$ \\
\hline$*$ & $01-1136$ & 6 & Zincite & 0.000 & 0.901 & $\mathrm{ZnO}$ \\
\hline$*$ & $21-0155$ & 2 & $\begin{array}{l}\text { Calcium } \\
\text { Oxide }\end{array}$ & 0.000 & 0.039 & $\mathrm{CaO}_{4}$ \\
\hline$*$ & $74-2392$ & 24 & Cobalt Oxide & 0.000 & 0.064 & $\mathrm{CoO}$ \\
\hline$*$ & $41-0753$ & 5 & $\begin{array}{l}\text { Calcium Iron } \\
\text { Oxide }\end{array}$ & 0.000 & 0.911 & $\mathrm{CaFeO}_{3}$ \\
\hline$*$ & $88-2434$ & 23 & $\begin{array}{l}\text { Palladium } \\
\text { Oxide }\end{array}$ & 0.000 & 0.180 & $\mathrm{PdO}$ \\
\hline$*$ & $18-0447$ & 5 & $\begin{array}{l}\text { Copper } \\
\text { Magnesium } \\
\text { Oxide }\end{array}$ & 0.000 & 0.089 & $\mathrm{Cu}_{3} \mathrm{MgO}_{4}$ \\
\hline$*$ & $12-0720$ & 7 & $\begin{array}{l}\text { Groutellite, } \\
\text { syn }\end{array}$ & 0.000 & 0.062 & $\mathrm{MnO}_{2}$ \\
\hline$*$ & $73-1704$ & 4 & $\begin{array}{l}\text { Nickel } \\
\text { Cobalt Oxide }\end{array}$ & 0.000 & 0.088 & $\mathrm{NiCo}_{2} \mathrm{O}_{4}$ \\
\hline$*$ & $83-0112$ & 2 & Iron Oxide & 0.000 & 0.041 & $\mathrm{Fe}_{21.34} \mathrm{O}_{32}$ \\
\hline$*$ & $75-1331$ & 4 & $\begin{array}{l}\text { Zinc } \\
\text { Bromide }\end{array}$ & 0.000 & 0.069 & $\mathrm{ZnBr}_{2}$ \\
\hline$*$ & $80-0728$ & 2 & $\begin{array}{l}\text { Potassium } \\
\text { Molybdenum } \\
\text { Oxide }\end{array}$ & 0.000 & 0.632 & $\mathrm{KMo}_{4} \mathrm{O}_{6}$ \\
\hline & & & & & \\
\hline
\end{tabular}

Table 4 Identified pattern list for $800^{\circ} \mathrm{C}$

\begin{tabular}{|c|c|c|l|c|c|c|}
\hline Visible & Ref. Code & Score & $\begin{array}{c}\text { Compound } \\
\text { Name }\end{array}$ & $\begin{array}{c}\text { Displacement } \\
{\left[{ }^{\circ} \mathbf{2 T h} .\right]}\end{array}$ & $\begin{array}{c}\text { Scale } \\
\text { Factor }\end{array}$ & $\begin{array}{c}\text { Chemical } \\
\text { Formula }\end{array}$ \\
\hline$*$ & $23-0493$ & 10 & $\begin{array}{l}\text { Potassium } \\
\text { Oxide }\end{array}$ & 0.000 & 0.099 & $\mathrm{~K}_{2} \mathrm{O}$ \\
\hline$*$ & $75-1526$ & 8 & Zincite & 0.000 & 0.084 & $\mathrm{ZnO}$ \\
\hline$*$ & $43-1004$ & 21 & Cobalt Oxide & 0.000 & 0.054 & $\mathrm{CoO}$ \\
\hline$*$ & $82-1691$ & 4 & Lime & 0.000 & 0.082 & $\mathrm{CaO}$ \\
\hline$*$ & $79-1741$ & 34 & Hematite, syn & 0.000 & 0.060 & $\mathrm{Fe}_{2} \mathrm{O}_{3}$ \\
\hline
\end{tabular}


Biodiesel Production from Coconut Oil using Heterogeneous Catalyst Derived from its Pod

\begin{tabular}{|c|c|c|l|c|c|c|}
\hline$*$ & $76-0442$ & 6 & $\begin{array}{l}\text { Cobalt Copper } \\
\text { Oxide }\end{array}$ & 0.000 & 0.024 & $\mathrm{CoCu}_{2} \mathrm{O}_{3}$ \\
\hline$*$ & $84-0155$ & 3 & $\begin{array}{l}\text { Potassium } \\
\text { Magnesium } \\
\text { Molybdenum } \\
\text { Oxide }\end{array}$ & 0.000 & 0.500 & $\mathrm{~K}_{2} \mathrm{Mg}_{2}($ \\
$\left.\mathrm{MoO}_{4}\right)_{3}$ & \\
\hline$*$ & $71-0399$ & 14 & Iron Zinc & 0.000 & 0.068 & $\mathrm{Fe}_{3} \mathrm{Zn}_{10}$ \\
\hline$*$ & $39-0892$ & 3 & $\begin{array}{l}\text { Potassium Iron } \\
\text { Oxide }\end{array}$ & 0.000 & 0.569 & $\mathrm{KFeO}_{2}$ \\
\hline$*$ & $42-1316$ & 10 & Ramsdellite & 0.000 & 0.133 & $\mathrm{MnO}_{2}$ \\
\hline
\end{tabular}

Table 5 Identified pattern list for $900^{\circ} \mathrm{C}$

\begin{tabular}{|c|c|c|c|c|c|c|}
\hline Visible & Ref. Code & Score & $\begin{array}{l}\text { Compound } \\
\text { Name }\end{array}$ & $\begin{array}{c}\text { Displacemen } \\
\mathbf{t}\left[{ }^{\circ} \mathbf{2 T h} .\right]\end{array}$ & Scale Factor & $\begin{array}{l}\text { Chemical } \\
\text { Formula }\end{array}$ \\
\hline$*$ & $23-0493$ & 10 & $\begin{array}{l}\text { Potassium } \\
\text { Oxide }\end{array}$ & 0.000 & 0.054 & $\mathrm{~K}_{2} \mathrm{O}$ \\
\hline * & $75-1526$ & 8 & Zincite & 0.000 & 0.175 & $\mathrm{ZnO}$ \\
\hline$*$ & 84-0307 & 29 & Iron Oxide & 0.000 & 0.094 & $\mathrm{Fe}_{2} \mathrm{O}_{3}$ \\
\hline$*$ & $74-2391$ & 25 & $\begin{array}{l}\text { Cobalt } \\
\text { Oxide }\end{array}$ & 0.000 & 0.601 & $\mathrm{CoO}$ \\
\hline * & $03-1123$ & 5 & Lime & 0.000 & 0.075 & $\mathrm{CaO}$ \\
\hline$*$ & $42-1316$ & 4 & Ramsdellite & 0.000 & 0.139 & $\mathrm{MnO} 2$ \\
\hline * & 80-1916 & 3 & $\begin{array}{l}\text { Copper } \\
\text { Oxide }\end{array}$ & 0.000 & 0.048 & $\mathrm{CuO}$ \\
\hline$*$ & $45-1267$ & 5 & $\begin{array}{l}\text { Calcium } \\
\text { Manganese } \\
\text { Oxide }\end{array}$ & 0.000 & 1.047 & $\mathrm{CaMnO}_{2.56}$ \\
\hline$*$ & $25-1402$ & 8 & $\begin{array}{l}\text { Maghemite- } \\
\text { ITQIRG, } \\
\text { syn }\end{array}$ & 0.000 & 0.066 & $\mathrm{Fe}_{2} \mathrm{O}_{3}$ \\
\hline$*$ & $75-2089$ & 7 & $\begin{array}{l}\text { Nickel } \\
\text { Manganese } \\
\text { Oxide }\end{array}$ & 0.000 & 1.137 & $\mathrm{NiMnO}_{3}$ \\
\hline$*$ & $85-0605$ & 13 & Delafossite & 0.000 & 0.103 & $\mathrm{CuFeO}_{2}$ \\
\hline$*$ & $43-1499$ & 6 & $\begin{array}{l}\text { Magnesium } \\
\text { Bromide }\end{array}$ & 0.000 & 0.102 & $\mathrm{MgBr}_{2}$ \\
\hline
\end{tabular}

The number of counts to the position of theta and the catalytic scores are also presented in Figures $1-3$. At $100{ }^{\circ} \mathrm{C}$, a $\mathrm{K}_{2} \mathrm{O}$ score of four (the lowest) was obtained (Figure 1). At $400{ }^{\circ} \mathrm{C}$, a $\mathrm{K}_{2} \mathrm{O}$ score of eight was obtained for the CPA samples. Figure 2 shows various scores of catalyst with $\mathrm{K}_{2} \mathrm{O}$ having a score of eight. At $600{ }^{\circ} \mathrm{C}$, a score of sixteen (highest) was obtained for $\mathrm{K}_{2} \mathrm{O}$. This CPA sample was eventually considered for biodiesel production. A $\mathrm{K}_{2} \mathrm{O}$ score of ten was obtained for CPA 800. This was found to have a $\mathrm{K}_{2} \mathrm{O}$ score which is less than $600{ }^{\circ} \mathrm{C}$ as shown in Figure 4. At $900{ }^{\circ} \mathrm{C}$, a score of ten was obtained for $\mathrm{K}_{2} \mathrm{O}$. The number of counts to the position of theta are shown in Figure 5 
Adebayo, A.O.; Oniya, O.O.; Ogunsola, D. A.; Ogunkunle, O; Bello, A.I. and Kuku, A.T

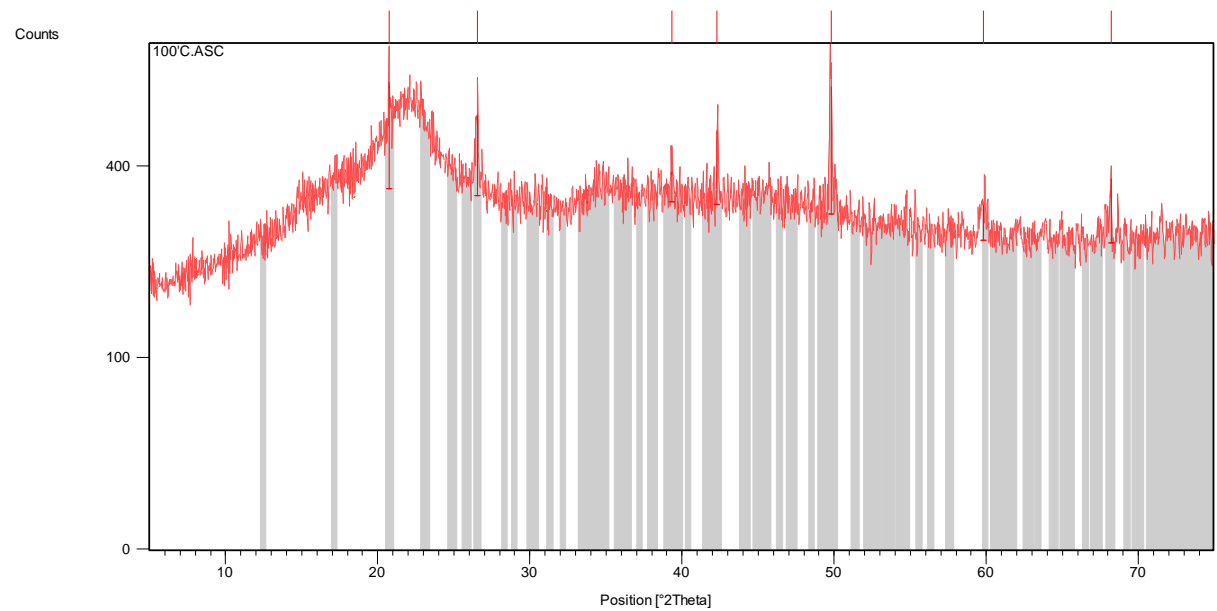

Figure 1 Position of theta to counts in $100^{\circ} \mathrm{C}$

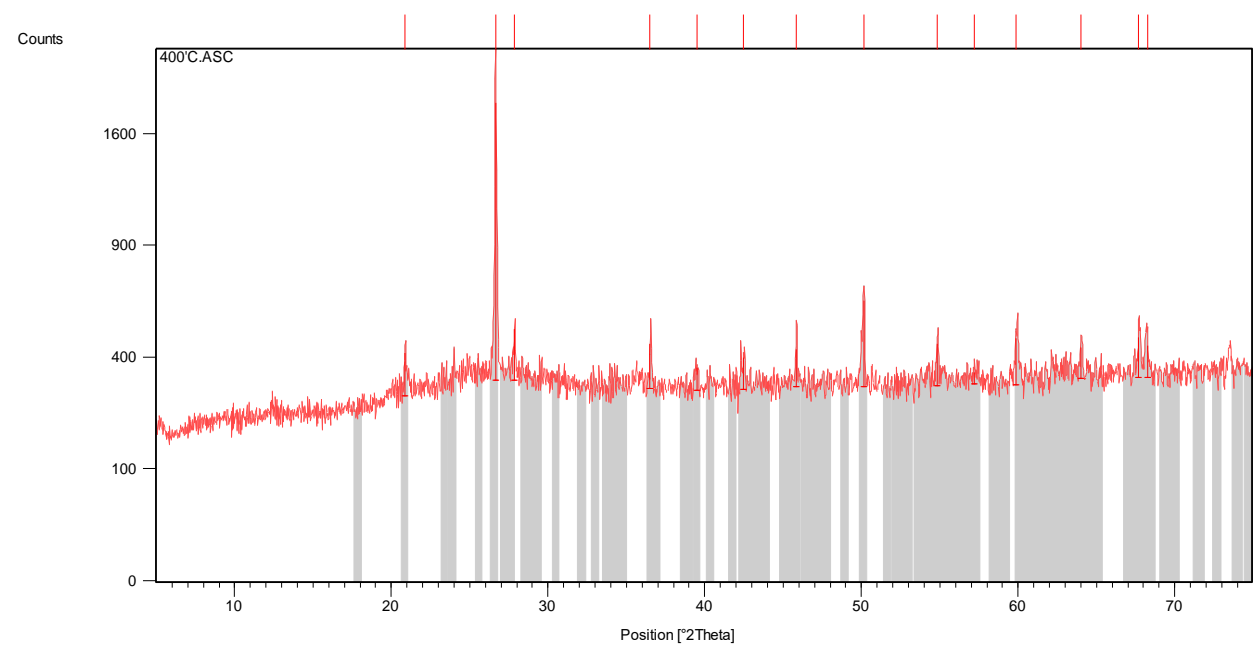

Figure 2 Position of theta to counts in $400^{\circ} \mathrm{C}$

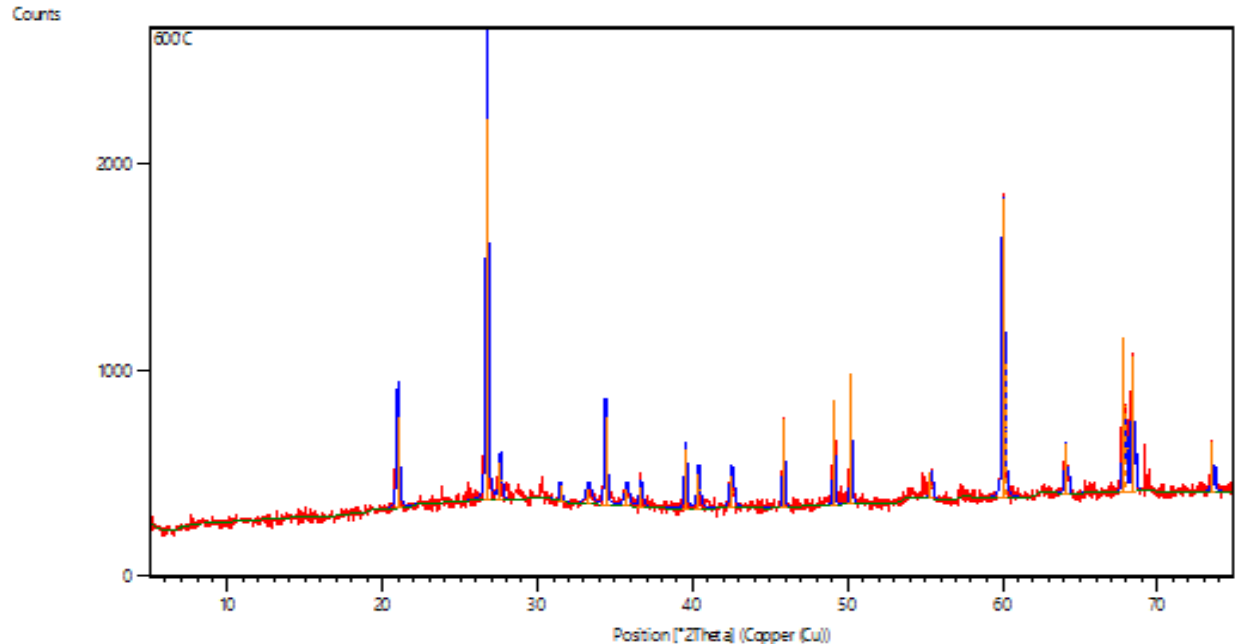

Figure 3 Position of theta to counts in $600^{\circ} \mathrm{C}$ 


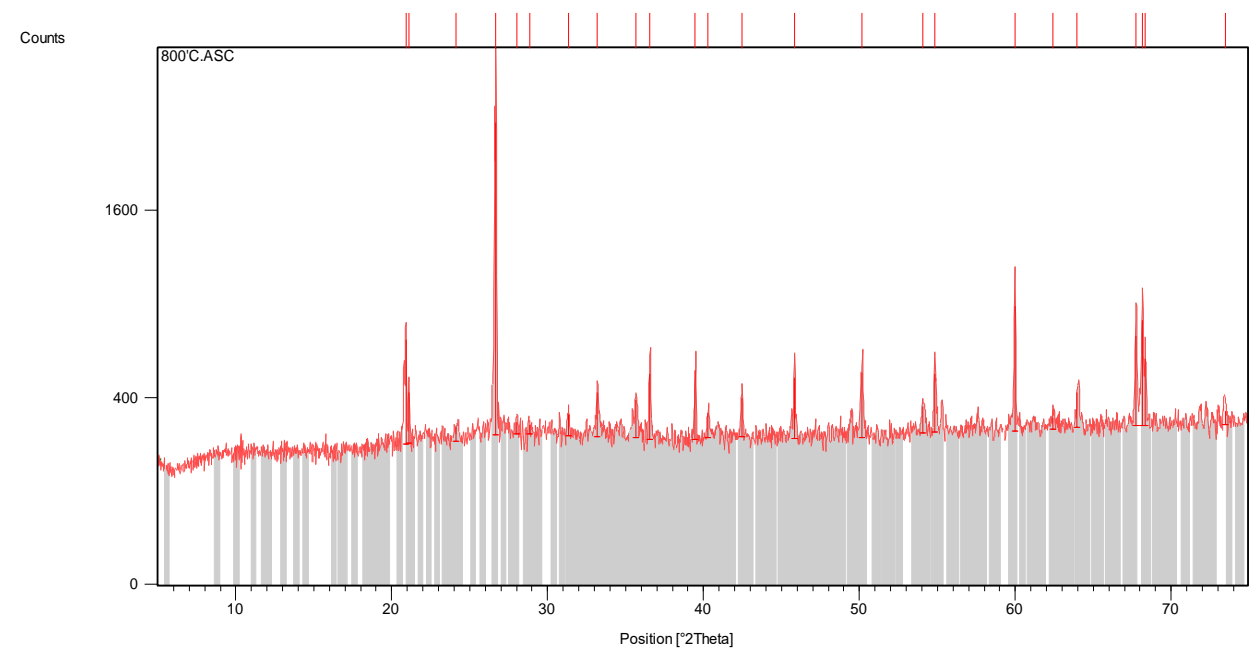

Figure 4 Position of theta to counts in $800^{\circ} \mathrm{C}$

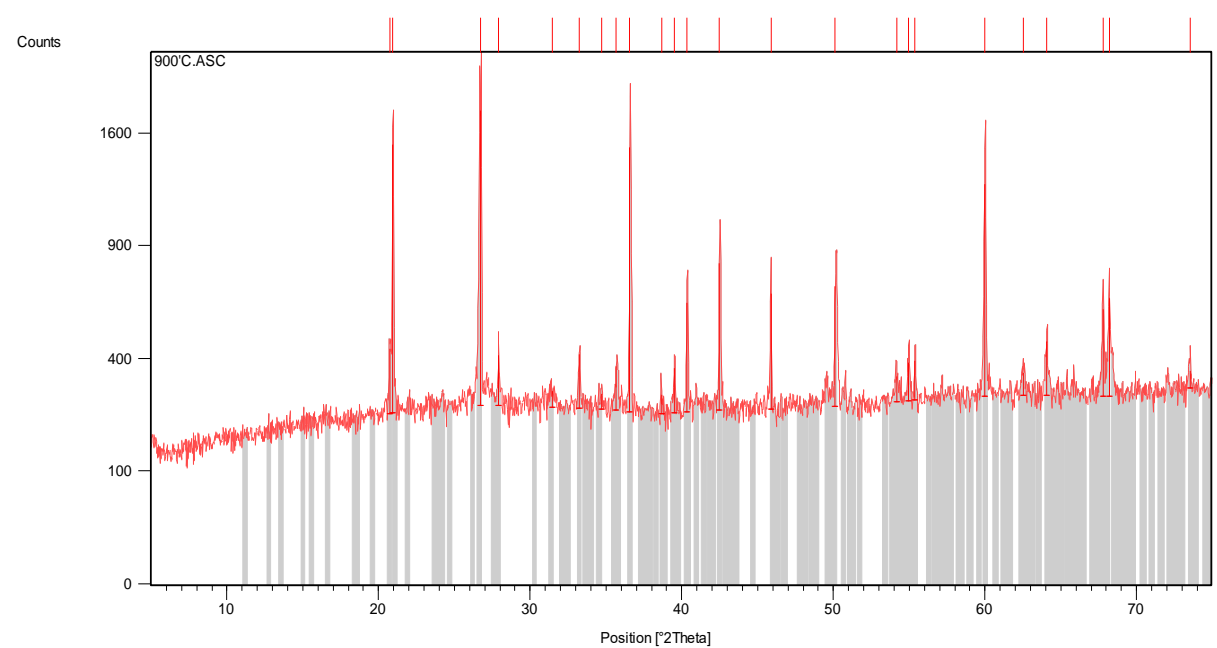

Figure 5 Position of theta to counts in $900^{\circ} \mathrm{C}$

The results obtained showed that we have the highest score of $\mathrm{K}_{2} \mathrm{O}$. It was noticed that the scores of $\mathrm{K}_{2} \mathrm{O}$ increased as temperature increased from $100{ }^{\circ} \mathrm{C}$ but stopped at $800{ }^{\circ} \mathrm{C}$. A temperature of $600{ }^{\circ} \mathrm{C}$ was found to be the optimum temperature. Consequently, the CPA sample prepared at $600{ }^{\circ} \mathrm{C}$ was used for biodiesel production. At optimum temperature of the catalyst, the pod size will be maximum when it has been heated to make the reactant to penetrate quickly. Immediately the optimum temperature is overshot, the pod size will shrink. Though it will be usable but will not be as effective as the catalyst prepared under optimum catalytic temperature.

\subsection{Biodiesel yields from Transesterification of Coconut Oil using Synthesized} $\mathrm{K}_{2} \mathrm{O}$

A total of $6 \mathrm{ml}$ of biodiesel was obtained from the transesterification of coconut oil. Even though this biodiesel yield was very low, more advanced extraction and production techniques can be used to increase the biodiesel yield. 


\section{CONCLUSIONS}

The use of coconut oil and its shell for biodiesel production has demonstrated a way of converting waste to wealth. The results obtained from the study clearly showed that renewable biodiesel can be synthesized using coconut oil. Also, the coconut shells can be used as a viable source of active heterogeneous catalyst for the transesterification process. The following conclusions were drawn from the results obtained.

- Highest $\mathrm{K}_{2} \mathrm{O}$ score was obtained at calcination temperature of $600{ }^{\circ} \mathrm{C}$.

- A total yield of $6 \mathrm{ml}$ of biodiesel was obtained using $180 \mathrm{ml}$ of ethanol, $20 \mathrm{ml}$ of oil (9:1 ratio) and $10 \%$ catalyst at a constant temperature (below ethanol boiling point) for 1hour.

The study has established the prospect of using heterogeneous catalyst derived from coconut pod to catalyze coconut oil. Advanced biochemical methods can be applied in improving the oil and biodiesel yields. For further studies and application of the biodiesel internal combustion engines, the physicochemical properties of the biodiesel product needs to be determined in accordance to international standards

\section{REFERENCES}

[1] Agyemang-Yeboah, F. (2011). Health Benefits of Coconut (Cocos nucifera Linn.) Seeds and Coconut Consumption. Nuts and Seeds in Health and Disease Prevention, 361-367. https://doi.org/10.1016/B978-0-12-375688-6.10043-X

[2] Akgün, N., \& İşcan, E. (2007). Effects of process variables for biodiesel production by transesterification. European Journal of Lipid Science and Technology, 109(5), 486-492. https://doi.org/10.1002/ejlt.200600210

[3] Archana, A., Vijay Pradhap Singh, M., Chozhavendhan, S., Gnanavel, G., Jeevitha, S. J., \& Muthu Kumara Pandian, A. (2020). Coconut Shell as a Promising Resource for Future Biofuel Production (pp. 31-43). https://doi.org/10.1007/978-981-15-0410-5_3

[4] Banković-Ilić, I. B., Stamenković, O. S., \& Veljković, V. B. (2012). Biodiesel production from non-edible plant oils. In Renewable and Sustainable Energy Reviews. https://doi.org/10.1016/j.rser.2012.03.002

[5] Baydar, H., \& Turgut, I. (1999). Variations of fatty acid composition according to some morphological and physiological properties and ecological regions in oilseed plants. Turkish Journal of Agriculture and Forestry, 23, 81-86. https://doi.org/10.3906/tar-96109

[6] Doll, K. M., Sharma, B. K., Suarez, P. A. Z., \& Erhan, S. Z. (2008). Comparing Biofuels Obtained from Pyrolysis, of Soybean Oil or Soapstock, with Traditional Soybean Biodiesel: Density, Kinematic Viscosity, and Surface Tensions. Energy \& Fuels, 22(3), 2061-2066. https://doi.org/10.1021/ef800068w

[7] Hossain, A. B. M. S., (Hossain, A., Nasrulhaq Boyce, A., (Boyce, A. N., A, N., Salleh, Salleh, A., Chandran, \& Somasundram, C. (2010). Biodiesel production from waste soybean oil biomass as renewable energy and environmental recycled process. African Journal of Biotechnology, 9, 4233.

[8] Jackson, J. C., Gordon, A., Wizzard, G., McCook, K., \& Rolle, R. (2004). Changes in chemical composition of coconut (Cocos nucifera) water during maturation of the fruit. Journal of the Science of Food and Agriculture, 84(9), 1049-1052. https://doi.org/https://doi.org/10.1002/jsfa.1783

[9] Kabir Ahmad, R., Anwar Sulaiman, S., Yusup, S., Sham Dol, S., Inayat, M., \& Aminu Umar, H. (2021). Exploring the potential of coconut shell biomass for charcoal production. Ain Shams Engineering Journal. https://doi.org/10.1016/J.ASEJ.2021.05.013 
[10] Keskin, A., Gürü, M., Altiparmak, D., \& Aydin, K. (2008). Using of cotton oil soapstock biodiesel-diesel fuel blends as an alternative diesel fuel. Renewable Energy, 33(4), 553-557. https://doi.org/10.1016/J.RENENE.2007.03.025

[11] Meneghetti, S. M. P., Meneghetti, M. R., Wolf, C. R., Silva, E. C., Lima, G. E. S., Coimbra, M. de A., Soletti, J. I., \& Carvalho, S. H. V. (2006). Ethanolysis of castor and cottonseed oil: A systematic study using classical catalysts. Journal of the American Oil Chemists 'Society, 83(9), 819-822. https://doi.org/10.1007/s11746-006-5020-3

[12] Narayana Reddy, J., \& Ramesh, A. (2006). Parametric studies for improving the performance of a Jatropha oil-fuelled compression ignition engine. Renewable Energy, 31(12), 1994-2016. https://doi.org/10.1016/J.RENENE.2005.10.006

[13] Obeng, G. Y., Amoah, D. Y., Opoku, R., Sekyere, C. K. K., Adjei, E. A., \& Mensah, E. (2020). Coconut Wastes as Bioresource for Sustainable Energy: Quantifying Wastes, Calorific Values and Emissions in Ghana. In Energies (Vol. 13, Issue 9). https://doi.org/10.3390/en13092178

[14] Ogunkunle, O., \& Ahmed, N. A. (2019). A review of global current scenario of biodiesel adoption and combustion in vehicular diesel engines. Energy Reports, 5, 1560-1579. https://doi.org/10.1016/j.egyr.2019.10.028

[15] Pham, L. J. (2016). Coconut (Cocos nucifera). Industrial Oil Crops, 231-242. https://doi.org/10.1016/B978-1-893997-98-1.00009-9

[16] Qiu, F., Li, Y., Yang, D., Li, X., \& Sun, P. (2011). Biodiesel production from mixed soybean oil and rapeseed oil. Applied Energy, 88(6), 2050-2055. https://doi.org/10.1016/J.APENERGY.2010.12.070

[17] Quintella, S. A., Saboya, R. M. A., Salmin, D. C., Novaes, D. S., Araújo, A. S., Albuquerque, M. C. G., \& Cavalcante, C. L. (2012). Transesterificarion of soybean oil using ethanol and mesoporous silica catalyst. Renewable Energy, 38(1), 136-140. https://doi.org/10.1016/J.RENENE.2011.07.011

[18] Ramadhas, A. S., Jayaraj, S., \& Muraleedharan, C. (2004). Use of vegetable oils as I.C. engine fuels-A review. Renewable Energy, 29(5), 727-742.

https://doi.org/10.1016/J.RENENE.2003.09.008

[19] Rashid, T. D. U., Anwar, F., \& Knothe, G. (2009). Evaluation of biodiesel obtained from cottonseed oil. Fuel Processing Technology, 90, 1157-1163.

https://doi.org/10.1016/j.fuproc.2009.05.016

[20] Reza Miri, S. M., Mousavi Seyedi, S. R., \& Ghobadian, B. (2017). Effects of biodiesel fuel synthesized from non-edible rapeseed oil on performance and emission variables of diesel engines. Journal of Cleaner Production, 142, 3798-3808. https://doi.org/10.1016/J.JCLEPRO.2016.10.082

[21] Singh, S. P., \& Singh, D. (2010). Biodiesel production through the use of different sources and characterization of oils and their esters as the substitute of diesel: A review. In Renewable and Sustainable Energy Reviews. https://doi.org/10.1016/j.rser.2009.07.017

[22] Tan, C. ., \& Che Man, Y. . (2002). Recent developments in differential scanning calorimetry for assessing oxidative deterioration of vegetable oils. Trends in Food Science \& Technology, 13(9-10), 312-318. https://doi.org/10.1016/S0924-2244(02)00165-6

[23] Vonortas, A., \& Papayannakos, N. (2014). Comparative analysis of biodiesel versus green diesel. WIREs Energy and Environment, 3(1), 3-23.

https://doi.org/https://doi.org/10.1002/wene.78

[24] Zhao, F., Zou, G., Shan, Y., Ding, Z., Dai, M., \& He, Z. (2019). Coconut shell derived biochar to enhance water spinach (Ipomoea aquatica Forsk) growth and decrease nitrogen loss under tropical conditions. Scientific Reports, 9(1), 20291. https://doi.org/10.1038/s41598-019-56663$\mathrm{w}$ 